\title{
Geomorphometric Analysis of Osman Sagar and Himayat Sagar Catchment Using Remote Sensing and GIS
}

\author{
N. Gangadhar ${ }^{1 *}$, G. Manojkumar ${ }^{1}$, R. Gajanan ${ }^{2}$ and Y. Siva Lakshmi ${ }^{3}$ \\ ${ }^{1}$ Department of Soil and Water Engineering, College of Agricultural Engineering Kandi, \\ Sangareddy Professor Jayashankar Telangana state agricultural university (PJTSAU), \\ Rajendranagar, Hyderabad, India \\ ${ }^{2}$ Department of Water Resource Division, TRAC, Hyderabad, India \\ ${ }^{3}$ Department of Agronomy College of agricultural engineering Kandi, Sangareddy Professor \\ Jayashankar Telangana state agricultural university (PJTSAU), Rajendranagar, India
}

*Corresponding author

\section{A B S T R A C T}

\section{Keywords}

Stream order,

Stream number,

Basin length, Mean

stream length,

Stream length

ratio, Bifurcation

ratio, Compactness

coefficient and

Rho-coefficient

Article Info

Accepted:

05 February 2020

Available Online:

10 March 2020
In the present study, analysis of geomorphometric characteristics of osman sagar and Himayat sagar catchment was carried out using remote sensing and GIS and the drainage networks of the both the catchment were generated using SRTM DEM (90 m resolutions). Two adjacent catchments, Himayath sagar and Osman sagar, located Rangareddy district of Telangana state, India were selected for study. Morphometric features and drainage network of Himayath sagar and Osman sagar catchments were extracted from DEM using ArcGIS software. Such as linear parameters viz, Stream order Stream number, basin length, mean stream length, stream length ratio, bifurcation ratio, Compactness coefficient and Rho-coefficient for both catchments were determined using ArcGIS.

\section{Introduction}

Water is known as the liquid for sustenance of life. All living beings are depending on water, without which no life exists on the earth. Earth has plentiful water due to the presence of hydrological cycle on it, but most of it is unfit for living beings use and consumption.
The study of the watershed morphometric analysis provides the beneficial parameters for the assessment of the groundwater potential zones, identification of sites for water harvesting structures, water resource management, runoff and geographic characteristics of the drainage system (Singh et al., 2014). Morphometric is the 
measurement and mathematical analysis of the configuration of the earth's surface, shape, dimension of its landforms (Clarke, 1996). Morphometry represents the topographical expression of land by way of area, slope, shape, length, etc. These parameters affect catchment stream flow pattern through their influence on concentration time. River characteristics are reasonably understood by the morphometric analysis of that particular river basin. Morphometric analysis requires measurement of linear features, gradient of channel network and contributory ground slopes of the drainage basin.

The morphometric parameters are divided into three categories: linear, areal and relief aspects (Sreedevi et al., 2009). The parameters namely area, perimeter, stream order and stream length are extracted from the geo-database and other parameters such as bifurcation ratio, stream length ratio, Rho coefficient, are calculated by means of various mathematical equations (Thomas et al., 2010).

Remote sensing techniques using satellite images are convenient tools for morphometric analysis. The satellite remote sensing has the ability to provide synoptic view of large area and is very useful in analyzing drainage morphometry. The image interpretation techniques are less time consuming than the ground surveys which coupled with limited field checks yield valuable results. Geographical Informational System (GIS) is a computer-assisted system designed to capture, store, edit, display and plot geographically referenced data.

\section{Materials and Methods}

This chapter briefly describes the details of the study area and the material and methods used including input parameters to achieve the selected research objectives. The delineation of watersheds from Digital Elevation Models (DEM), determination of morphometric parameters.

\section{Study area}

The study area for the present work consists of catchment of Himayat sagar and Osman sagar reservoirs (Fig.1). Himayat sagar reservoir was constructed on Esa River in 1925 and is situated $9.6 \mathrm{~km}$ in southwest direction from Hyderabad, located at $17^{\circ} 02^{\prime} 00^{\prime \prime} \mathrm{N}$ to $17^{\circ} 21^{\prime} 15^{\prime \prime} \mathrm{N}$ latitude and $77^{\circ} 53^{\prime} 49^{\prime \prime} \mathrm{E}$ to $78^{\circ} 26^{\prime} 48^{\prime \prime} \mathrm{E}$ longitude. Osman sagar reservoir was constructed on Musi river in 1922 and is situated $9.6 \mathrm{~km}$ from Hyderabad in western direction located at $17^{\circ} 14^{\prime} 31^{\prime \prime} \mathrm{N}$ to $17^{\circ} 29^{\prime} 50^{\prime \prime} \mathrm{N}$ latitude and $77^{\circ} 50^{\prime} 30^{\prime \prime} \mathrm{E}$ to $78^{\circ} 20^{\prime} 4^{\prime \prime} \mathrm{E}$ longitude. The catchment area of Himayat sagar is 1358.53 $\mathrm{km}^{2}$ with elevation range of $516 \mathrm{~m}$ to $730 \mathrm{~m}$. Where the Osman sagar catchment area consists of $746.73 \mathrm{~km}^{2}$ with elevation varies between $522 \mathrm{~m}$ to $722 \mathrm{~m}$. Both reservoirs supply drinking water to Hyderabad city. The study area is pertaining to K6Dm4 AgroEcological sub region. It is part of North Telangana Plateau, hot moist semi-arid eco sub-region with deep loamy and clayey mixed red and black soils having very high available water content and 120-150 days growing period.

\section{Remote sensing data}

Topographic data: Shuttle Radar Topography Mission Digital Elevation Model (SRTM DEM) version 4.1 with a $90 \mathrm{~m}$ resolution was downloaded from http://srtm.csi.cgiar.org.

\section{Catchment delineation}

Catchment area is delineated from a DEM by computing the flow direction. To determine the contributing area, a raster representing the direction of flow is created. Once the 
direction of flow out of each cell is known, it is possible to determine which and how many cells flow into any given cell. This information is used to define catchment boundaries. A series of steps are preceded to delineate catchment and to define stream network. A process flowchart is depicted in Fig.2.

\section{Morphometric parameters estimation}

Morphometric analysis is the measurement of the three-dimensional geometry of landforms and has traditionally been applied to watershed, drainages, hill slopes and other group of terrain features (Babar, 2005). Drainage basin or basins should be the study area for better understanding of the hydrologic system. Basin morphometry is a means of numerically analyzing or mathematically quantifying aspects of drainage channels. Spatial arrangement of streams has given rise to a particular design which is called the drainage pattern. Morphometric analysis requires measurement of linear features, gradient of channel network and contributory ground slopes of the drainage basin. Geographic information system and remote sensing satellite images are convenient tools for morphometric analysis. To estimate the morphometric features of catchments of Himayath sagar and Osman sagar reservoirs, the drainage network was extracted from digital elevation model in ArcGIS software. Catchment areas of Himayath sagar and Osman sagar were extracted from SRTM DEM version 4.1, with a $90 \mathrm{~m}$ resolution using hydrology tool of ArcGIS. Geomorphometric characteristics such as linear, areal and relief aspect parameters for both catchments were determined using ArcGIS. Figure 3.3 shows methodology of geomorphometric analysis of Himayath sagar and Osman sagar catchments. order and so on. A lower order stream, such as one of the first order joining another higher order does not alter the rank of the later. The relevant numbers were entered into the attribute table of the drainage network using ArcGIS software

\section{Stream order}

The first step in drainage basin analysis is to designate the stream order. Stream order is introduced by Horton (1945). Later it is modified by Strahler (1964). The smallest streams of the network, which have no tributaries, are called first order streams. When two first order streams join together, they form a second order stream and further along its course this stream may join another second order channel to form one of the third orders and so on. A lower order stream, such as one of the first order joining another higher order does not alter the rank of the later. The relevant numbers were entered into the attribute table of the drainage network using ArcGIS software.

\section{Basin length}

It is the distance from the outlet to the most remote point on the basin.

\section{Mean length}

Mean length of channel of order the total length is divided by the number of segments of that order.

$L_{U}=\frac{L_{u}}{N_{u}} \cdots(\mathrm{i})$

where, ${ }^{L}$ uis total length of all orders; $N_{\text {uis }}$ total number of segments

\section{Stream length ratio}

It is the ratio of the mean length of segments of order to the mean length segment of the next lower order. Horton (1945 
$R_{l}=\frac{L_{u}}{L_{u-1} \cdots(\mathrm{ii})}$

where, ${ }^{L_{\text {uis }}}$ the mean length of segments of order; ${ }^{L_{u-1}}$ is the mean length of segments of next order

\section{Bifurcation ratio}

The term bifurcation ratio $(\mathrm{Rb})$ may be defined as the ratio of the number of the stream segments of given order to the number of segments of the next higher order (Schumn,1956)

$R_{b}=\frac{N_{u}}{N_{u+1}} \cdots$ (iii)

Where,is total no. of stream segments of order $\mathrm{u}, N_{u+1 \text { is }}$ No. of segments of next higher order

\section{Compactness coefficient}

The compactness factor was obtained from the ratio of the perimeter of the basin to the total drainage basin area. (Gupta, 1999)

$C_{c}=\frac{P}{2 \times \sqrt{\pi \times A}} \cdots($ iv)

Where, $C_{\text {cis }}$ the compactness factor; $\mathrm{P}$ is the perimeter of the basin; A is the unit area of the basin.

\section{Rho-coefficient}

Rho coefficient is an important parameter described by the Horton, 1945 using the stream length ratio divided by the bifurcation ratio and is an important parameter relating drainage density to physiographic development of a watershed which facilitate evaluation of storage capacity of drainage network and hence, a determinant of ultimate degree of drainage development in a givenwatershed.
$\rho=\frac{L_{u r}}{R_{b}} \cdots(\mathrm{v})$

Where, ${ }^{L}$ uris the stream length ratio, $R_{b}$ is the bifurcation ratio.

\section{Results and Discussion}

\section{Catchment Delineation}

Delineation of the catchment area is the first step of the geomorphometric analysis. The process mentioned in section 2 . is used to delineate catchment area of Himayath sagar and Osman sagar reservoirs. DEM is prepared from the SRTM data of version 4.1 with a 90 $\mathrm{m}$ resolution. DEM of study area is depicted in Fig.3 Flow direction raster created from DEM is used to delineate the catchment area (Fig.4). Catchment of Himayath sagar and Osman sagar is presented in Fig.5. The catchment area of Himayath sagar and Osman sagar are $1358.53 \mathrm{~km}^{2}$ and $746.73 \mathrm{~km}^{2}$, respectively. It is found that catchment area of Himayath sagar is 1.82 times greater than Osman sagar.

\section{Morphometric parameters estimation}

In morphometric analysis, configuration of the earth's surface and dimensions of the landforms is measured. This analysis was carried out for quantitative evaluation of drainage basin. Three major aspects: Linear, Areal and Relief have been described for analysis. Linear aspect in morphometry is characterized by basin length, stream order, stream number, stream length and bifurcation ratio. Areal aspect represents the characteristics of catchment area and describes how catchment area controls and regulates the hydrological behavior. Relief aspect defines terrain setup of the catchment and terrain characteristics. The geomorphometric parameters of the Himayath sagar and Osman sagar catchments were 
carried out using SRTM DEM with $90 \mathrm{~m}$ spatial resolution. Examined parameters are presented in detailed in following sections.

Stream ordering has been carried out using Strahler method (1964). Stream order of the study area of Himayath sagar ranges from 1 to 7. Whereas the stream order for Osman sagar varies from 1 to 6 . Figure 6 shows stream order map of both catchment. It is observed that the maximum frequency is in the case of first order streams and there is a decrease in stream frequency as the stream order increases.

Basin length is the distance from the outlet to the most remote point on the basin. Length of the basin of Himayath sagar catchment is $52.92 \mathrm{~km}$ whereas the length of the basin of Osman sagar catchment is $50.49 \mathrm{~km}$. Stream length is computed based on the Horton law (1945). The total stream length of Himayath sagar catchment is $2592.96 \mathrm{~km}$ whereas the total stream length of the basin for Osman sagar catchment is $1510.46 \mathrm{~km}$. It is found that Ist order streams have the maximum length compared to that of other orders. Stream length decreases as stream order increases. Stream length against stream order is shown in Fig. 7
Mean stream length of study catchments is calculated as ratio of total length of all streams to number of streams. Mean stream length of Himayath sagar and Osman sagar catchment is $1354.73 \mathrm{~km}$ and $789.16 \mathrm{~km}$, respectively. Main stream length of Himayath sagar and Osman sagar catchments are 65.76 $\mathrm{km}$ and $58.89 \mathrm{~km}$, respectively. The time of concentration along main stream is always greatest. Stream length ratio of Himayath sagar and Osman sagar catchment is 1.263 and 0.474 , respectively. Generally, its value of the given order is greater than that of the lower order and less than that of its next higher order. Changes in stream length ratio from one order to another indicate the late youth to mature stage of the geomorphic development (Singh and Singh, 1997). Bifurcation ratio is an index of relief and dissection (Horton, 1945 and Schumm, 1956). Bifurcation ratio of Himayath sagar catchment varies from 2.0 to 4.87 and mean bifurcation ratio is 3.78 . Bifurcation ratio of the Osman sagar catchment varies from 3.11 to 7.00 and mean bifurcation ratio is 4.5. Table 1 presents bifurcation ratio analysis for both catchments. It has been found that the mean bifurcation ratio characteristically ranges between 3.78 and 4.5 for both catchments.

Table.1 Table .1Bifurcation ratio analysis for Himayath sagar and Osman sagar catchments

\begin{tabular}{|c|c|c|c|c|}
\hline \multirow{2}{*}{$\begin{array}{l}\text { Stream } \\
\text { order }\end{array}$} & \multicolumn{2}{|c|}{ Himayath sagar } & \multicolumn{2}{|c|}{ Osman sagar } \\
\hline & No of streams & $\begin{array}{c}\text { Bifurcation } \\
\text { ratio }\end{array}$ & No of streams & $\begin{array}{c}\text { Bifurcation } \\
\text { ratio }\end{array}$ \\
\hline 1 & 2318 & & 1439 & \\
\hline 2 & 605 & 3.83 & 355 & 4.05 \\
\hline 3 & 129 & 4.68 & 87 & 4.08 \\
\hline 4 & 39 & 3.30 & 28 & 3.11 \\
\hline 5 & 7 & 4.87 & 4 & 7.00 \\
\hline 6 & 2 & 4.00 & 1 & 4.00 \\
\hline 7 & 1 & 2.00 & & \\
\hline \multicolumn{2}{|c|}{ Mean } & 3.78 & & 4.45 \\
\hline
\end{tabular}


Fig.1 Location of study area

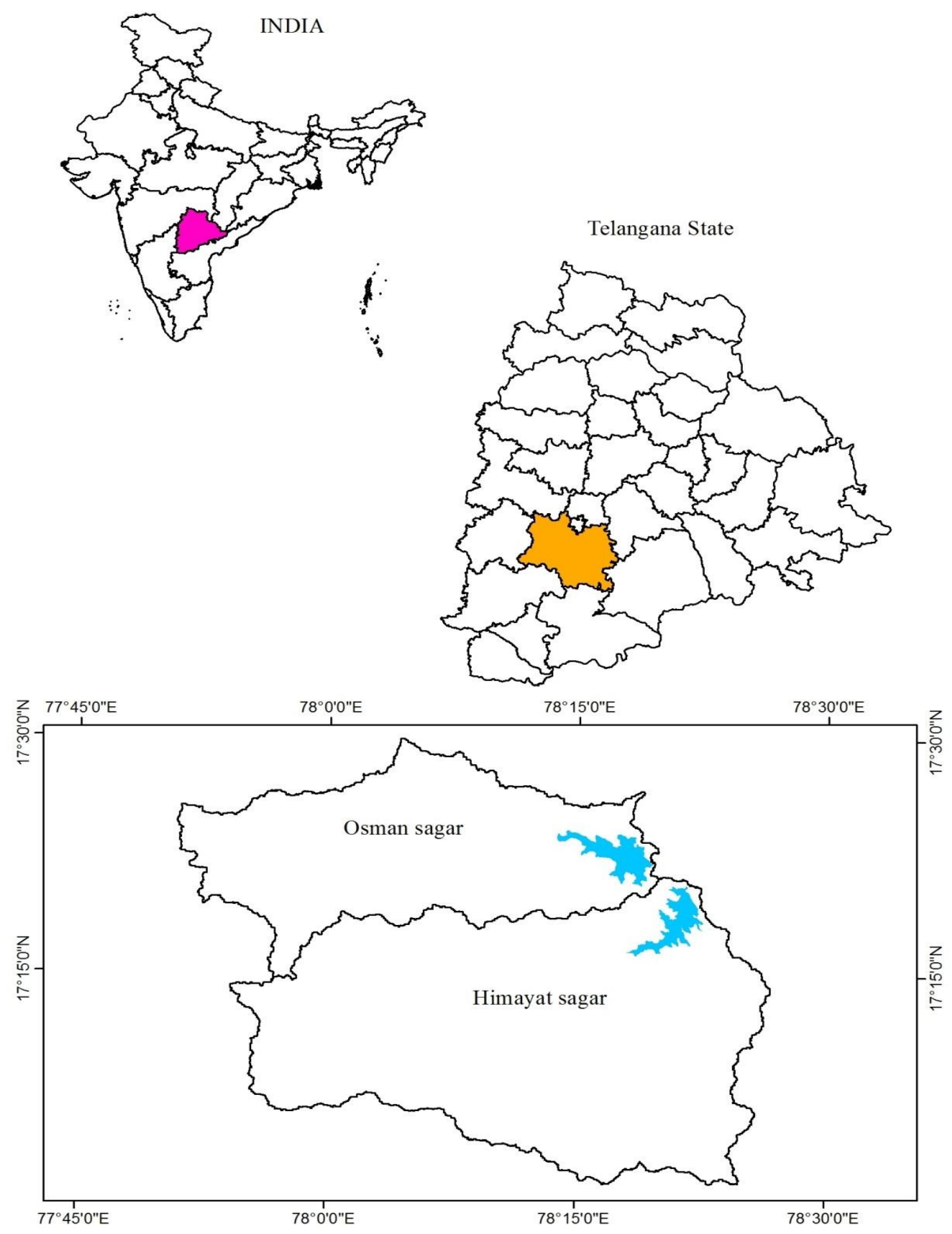


Fig.2 Flow chart for catchment delineation

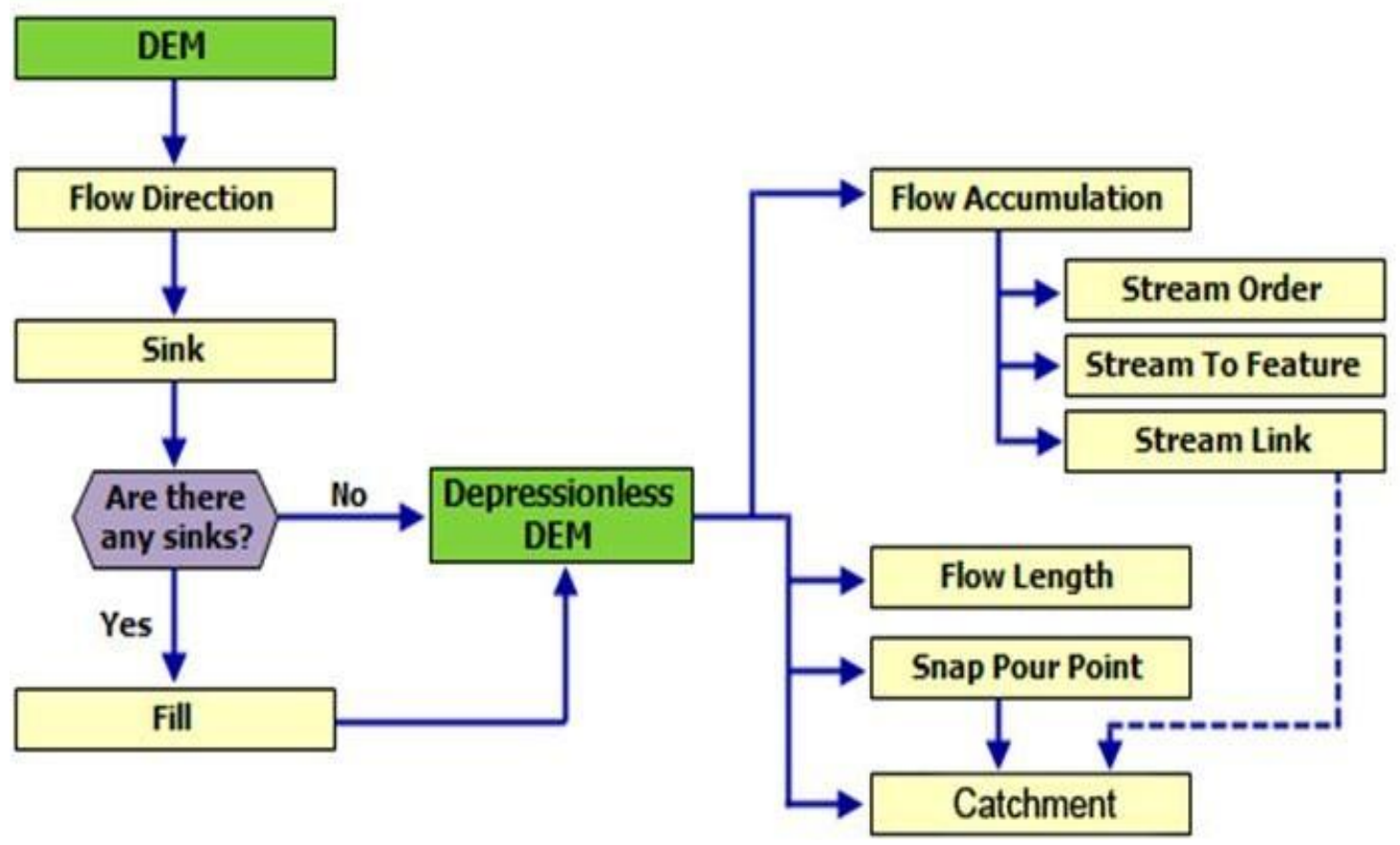

Fig.3 Digital elevation model representation of study area

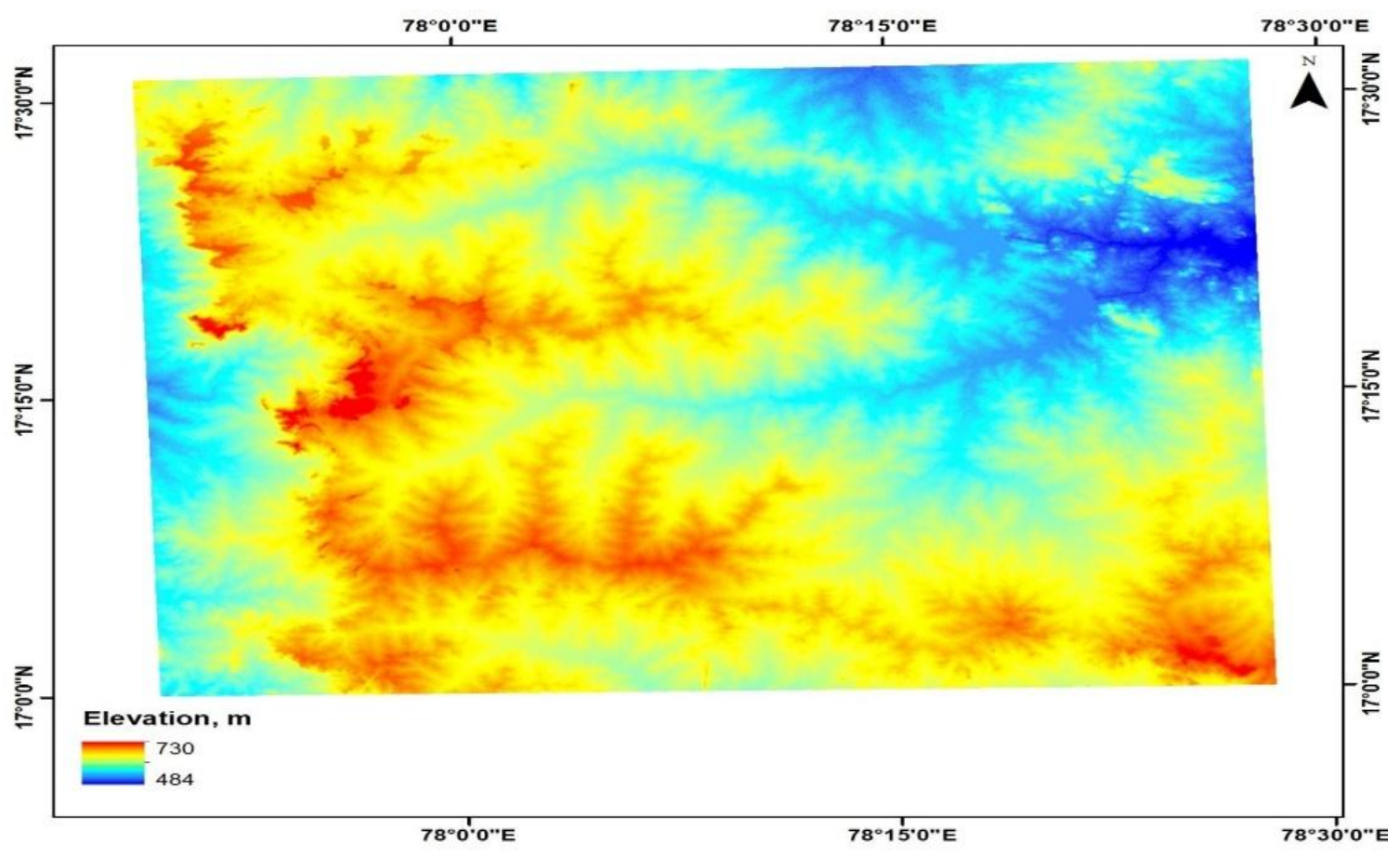


Fig.4 Flow direction map of study area

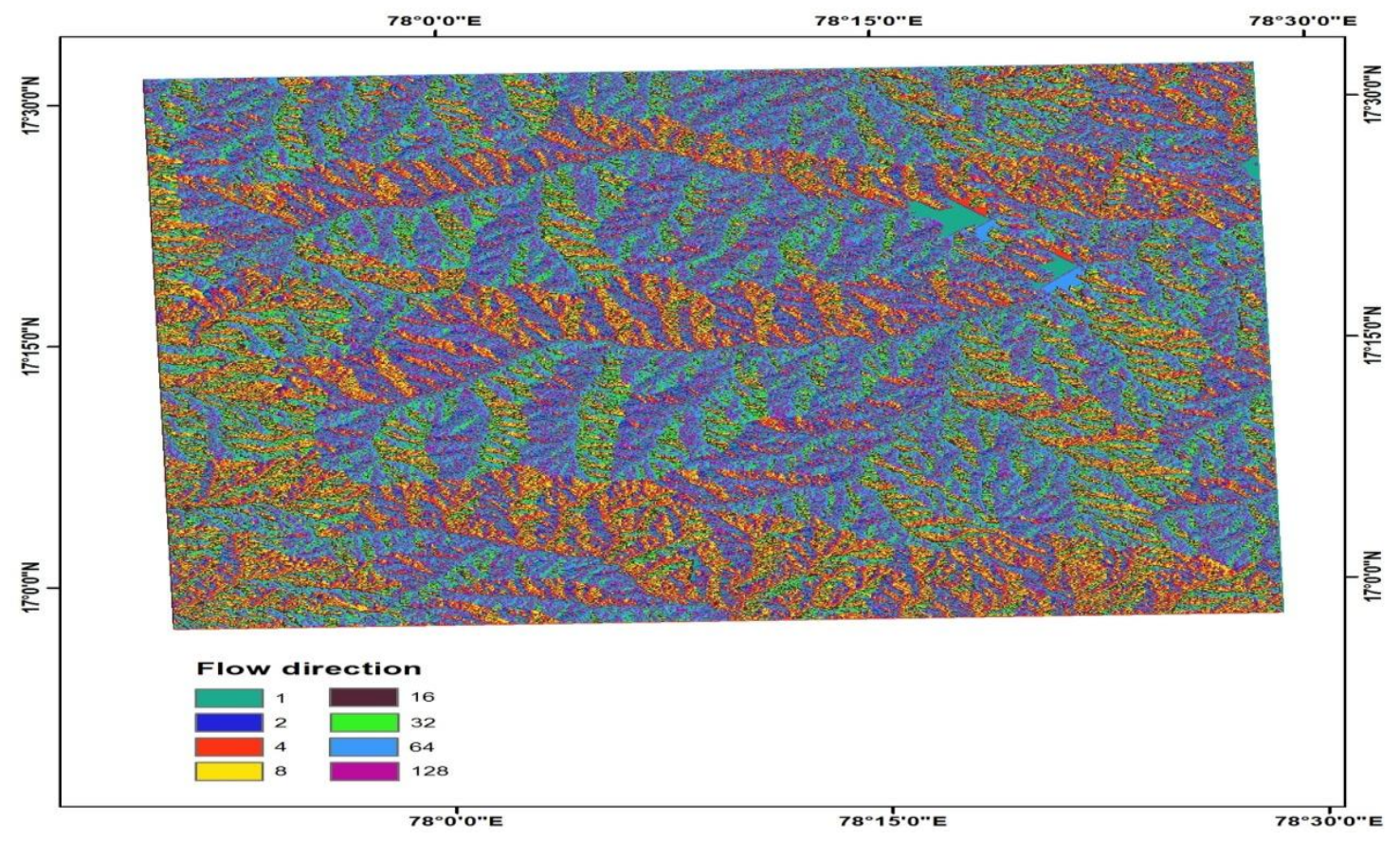

Fig.5 Catchment of Himayath sagar and Osman sagar reservoirs

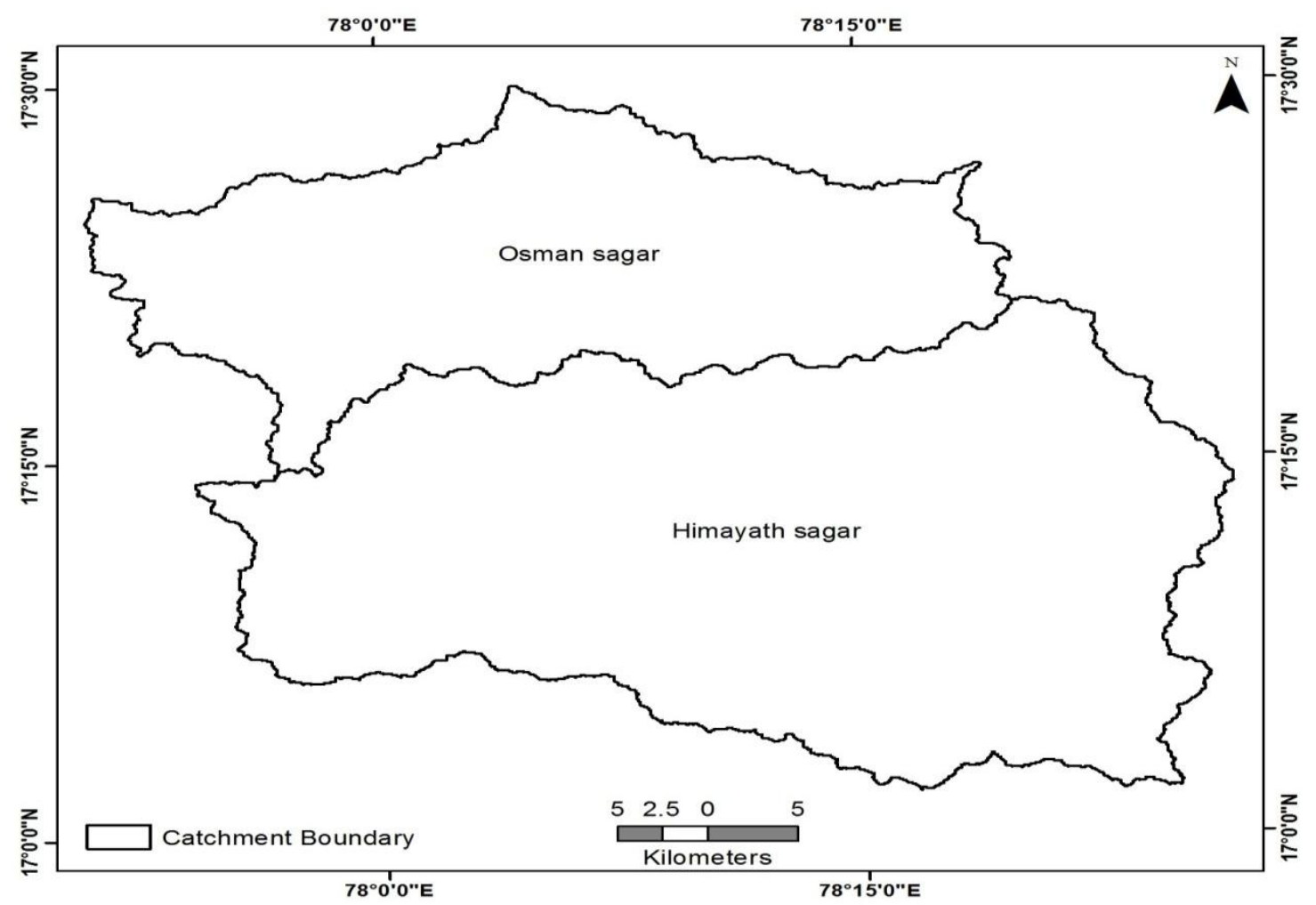


Fig.6 Stream order map of Himayath sagar and Osman sagar catchments

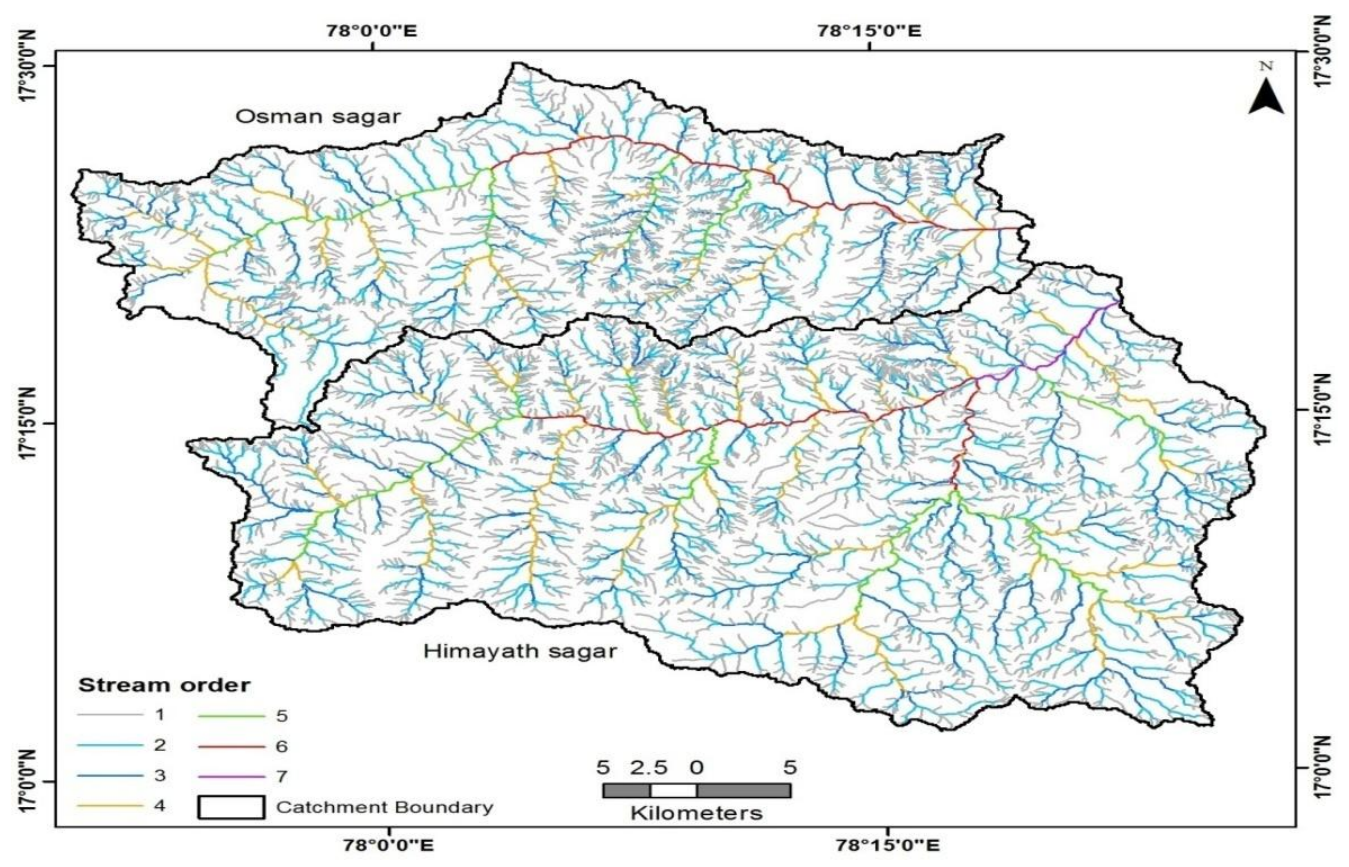

Fig.7 Stream length and stream order of Himayath sagar and Osman sagar catchments

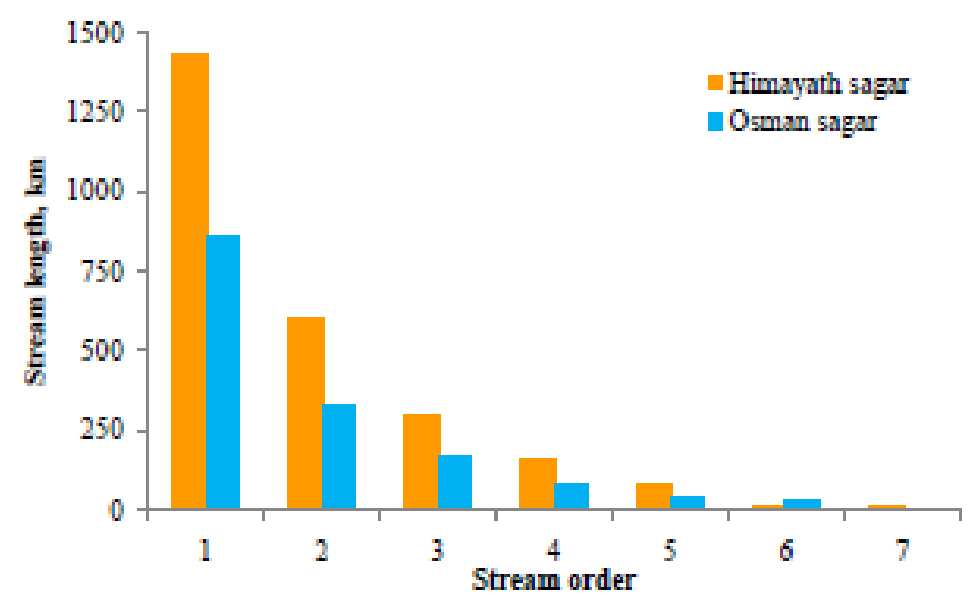

Bifurcation ratio with low value means no structural disturbances and a high value means the existence of strong structural control on the catchment. Mean bifurcation ratio of less than 5 for study area shows that geology is reasonably homogeneous without structural disturbances to the drainage basin.

Compactness coefficient of Himayath sagar and Osman sagar catchment is found to be
1.980 and 2.316, respectively. It reflects that Himayath sagar catchment have less elongated shape than Osman sagar catchment. However, both catchments has high time of concentration of surface flow. Rho coefficient of Himayath sagar and Osman sagar catchment is 0.33 and 0.12 , respectively. Rho coefficient of both catchments indicates low storage capacity of drainage network and hydrologic storage during floods. 
Summary and conclusions of the study are as follows:

Growing population, urbanization and industrialization are leading to overutilization of water resources, thus exerting pressure on the limited civic amenities many of which are on the brink of collapse. Assessment of water resources quantitatively is being critical task on account of everincreasing demand for water over past. Water plays principal role in the sustainability of livelihoods, agriculture and regional economy. Water management is the primary safeguard against drought and plays a fundamental role in achieving food security at the watershed, sub basin and basin from local to globalplanes. The study of the watershed morphometric analysis provides the beneficial parameters for the assessment of the groundwater potential zones, identification of sites for water harvesting structures, water resource management, runoff and geographic characteristics of the drainage system.

Morphometry represents the topographical expression of land by way of area, slope, shape, length, etc. These parameters affect catchment stream flow pattern through their influence on concentration time. River characteristics are reasonably understood by the morphometric analysis of that particular river basin. Morphometric analysis requires measurement of linear features, gradient of channel network and contributory ground slopes of the drainage basin. Considering the above facts, the present study focuses on the analysis of geomorphometric characteristics in the two adjacent catchments. The specific objectives of the study are as follows to analyse geomorphometric characteristics of Himayath sagar and Osman sagar catchment using RS and GIS. Particular to the present study, the following salient conclusions are drawn.
1. A GIS technique characterized by very high accuracy of mapping and measurement proves a competent tool in geomorphometric analysis.

2. Geomorphometric analysis shows both catchment areas have elongated shape and high time of concentration of surface flow.

3. Mean bifurcation ratio of less than 5 for both catchments shows geology is reasonably homogeneous.

\section{References}

Chopra, R., Dhiman, R. D., and Sharma, P. K. 2005. Morphometric analysis of subwatersheds in Gurdaspur district, Punjab using remote sensing and GIS techniques. Journal of the Indian Society of Remote Sensing, 33(4), 531.

Chopra, R., Dhiman, R. D., and Sharma, P. K. 2005. Morphometric analysis of subwatersheds in Gurdaspur district, Punjab using remote sensing and GIS techniques. Journal of the Indian Society of Remote Sensing. 33(4):531539

Clarke, J.I. (1996), Morphometry from Maps, Essays in Geomorphology, Elsevier publication. Co, New York, pp 235274.

Farhan, Y., Anbar, A., Enaba, O., and AlShaikh, N. 2015. Quantitative analysis of geomorphometric parameters of WadiKerak, Jordan, using remote sensing and GIS. Journal of Water Resource and Protection. 7(06): 456475

Horton, R. E. 1945. Erosional development of streams and their drainage basins; hydrophysical approach to quantitative morphology. Geological society of Americabulletin,56(3), 275-370.

Kiran Kumar, K. M., Govindaiah, S., and Nagabhushan, P. 2017. Morphometric 
Analysis of the Tumkur-Gubbi Watershed of Shimsha River Basin, Karnataka, India, by using Remote Sensing and GIS Techniques. International Journal of Creative Research Thoughts (IJCRT).6(1):16281640

Pareta, K., and Pareta, U. 2012. Quantitative geo morphological analysis of a watershed of Ravi River Basin, HP India. International Journal of Remote Sensing and GIS.1(1): 41-56.

Singh, P., Gupta, A., and Singh, M. (2014). Hydrological inferences from watershed analysis for water resource management using remote sensing and GIS techniques. The Egyptian Journal of Remote Sensing and Space Science, 17(2), 111-121.

Soni, S. K., Tripathi, S., and Maurya, A. K. 2013. GIS based morphometric characterization of mini-watershedRachhar Nala of Anuppur District Madhya Pradesh. International Journal of Advanced Technology and Engineering Research (IJATER). 3(3):32-38.

Sreedevi, P. D., Owais, S., Khan, H. H. and Ahmed, S. 2009. Morphometric analysis of a watershed of South India using SRTM data and GIS. Journal of the geological society of India.
73(4):543-552.

Strahler, A. N. 1957. Quantitative analysis of watershed geomorphology. Eos, Transactions American Geophysical Union, 38(6), 913-920.

Thomas, J., Joseph, S. and Thrivikramaji, K. P. 2010. Morphometric aspects of a small tropical mountain river system, the southern Western Ghats, India. International Journal of Digital Earth. 3(2): 135-156.

V. E. 2015. Morphometric evaluation of watersheds in Caxias do Sul City, Brazil, using SRTM (DEM) data and GIS. Environmental Earth Sciences. 73(9): 5677-5685.

Varalakshmi, V. 2015. Morphometric analysis of the Catchments of Himayatsagar and Osmansagar Reservoirs-Hyderabad. Engineering and Scientific International Journal, 2(1),

Vieceli, N., Bortolin, T. A., Mendes, L. A., Bacarim, G., Cemin, G., and Schneider,

Vittala, S. S., Govindaiah, S., and Gowda, H. H. 2004. Morphometric analysis of subwatersheds in the Pavagada area of Tumkur district, South India using remote sensing and GIS techniques. Journal of the Indian Society of Remote Sensing. 32(4): 351-362.

\section{How to cite this article:}

Gangadhar, N., G. Manojkumar, R. Gajanan and Siva Lakshmi, Y. 2020. Geomorphometric Analysis of Osman Sagar and Himayat Sagar Catchment Using Remote Sensing and GIS. Int.J.Curr.Microbiol.App.Sci. 9(03): 786-796. doi: https://doi.org/10.20546/ijcmas.2020.903.093 